\title{
ПРОБЛЕМА ДОСЛІДЖЕННЯ КОНФЛІКТНОЇ ПОВЕДІНКИ В ЮНАЦЬКОМУ ВЩЦ (ГЕНДЕРНИЙ АСПЕКТ)
}

У статті розкрито зміст понять «конфлікт» $i$ «конфліктні відносини». Виокремлено основні положення науковців щэодо феномену міжособистісного конфлікту, здійснено узагальнення щзодо стратегій поведінки у конфлікті. Визначено, щуо характер поведінки людини у конфлікті залежить як від об'єктивних умов його протікання, так $і$ від соиіальних характеристик його учасників, зокрема гендерних розбіжностей. Встановлено, щц поведінка юнаків та юнок у вирішенні конфлікту суттєво відрізнясться - вони по-різному сприймають иілі спілкування, усвідомлюють цінність самого конфлікту і різняться стратегіями вирішення суперечок.

Ключові поняття: конфлікт, конфліктна ситуація, конфліктність, юнацький вік, гендерні відмінності.

В статье раскрыто содержание понятий «конфликт» $и$ «конфликтные отнотения». Изложены основные положения теории межличностного конфликта и стратегий поведения в конфликтной ситуации. Определено, что характер поведения человека в конфликте зависит как от объективных условий его протекания, так и от сочиальных характеристик его участников, в частности гендерных различий. Установлено, что поведение юномей и девушек в решении конфликта существенно отличается - они по-разному воспринимают иели общения, осознают ценность самого конфликта и отличаются стратегиями разрешения споров.

Ключевые понятия: конфликт, конфликтная ситуация, конфликтность, юноческий возраст, гендерные различия.

Постановка проблеми. Актуальність дослідження гендерних особливостей конфліктної поведінки в юнацькому віці обумовлена специфічними явищами, що свідчать про перехід від дитинства до дорослості, що супроводжується якісною перебудовою усіх сторін розвитку особистості і необхідністю погоджувати свої потреби з вимогами суспільства. До того ж, на сучасному етапі розвитку України умови становлення особистості молоді стають все більш підвладними впливу кризових явищ політичного, суспільного, економічного характеру. Уявлення про гендер у суспільстві виконують регулювальну функцію, обумовлюючи особливості поведінки жінок і чоловіків у різних умовах, відображаючись в установках, мотиваційній сфері тощо. Суспільство очікує від своїх членів 
певної поведінки та «виховує» у них певні поведінкові стратегії згідно їхньої гендерної належності, визначаючи «нормативну» реакцію на різні життєві події для жінок та чоловіків [10, с. 94]. . Одним 3 основних завдань юнацького віку $є$ набуття ідентичності, в тому числі і гендерної. Гендер є однією 3 фундаментальних ознак особистості, яка здійснює вплив на ії поведінку у будь-яких умовах, в тому числі і у складних, конфліктних ситуаціях. Виникнення суперечностей в юнацькому віці часто супроводжується сильними емоційними переживаннями, порушеннями у поведінці, у взаєминах 3 дорослими та ровесниками.

Аналіз останніх досліджень та публікацій. Означені аспекти знайшли своє відображення у низці наукових праць, присвячених дослідженню питання гендерних особливостей конфліктної поведінки, врахування яких може сприяти підвищенню ії ефективності.

Проблемі конфліктної поведінки присвячені наукові розвідки вітчизняних та зарубіжних вчених (О. Ф. Бондаренка, Ф. М. Бородкіна, Ф. Є. Василюка, Н. В. Грішиної, Р. Дарендорфа, М. Дойча, О. О. Єршова, А. Т. Ішмуратова, Л. М. Карамушка, Л. Козера, І. Н.Коряка, К. Левіна, Г. В. Ложкіна, Е. Мейо, Т. Парсонса, Л. О. Петровської, М. І. Пірена, К. К. Платонова, Н. І. Пов'якель, К. Хорні, З.Фрейда та ін.) У наукових доробках Н. В. Грішиної, Є.І. Степанова, Н.А. Макарчук зроблені спроби виділити детермінанти власне конфліктної поведінки. В. М. Басова та А. І. Шкіль та ін. вивчали конфліктність у молодіжних та студентських групах. У дослідженнях В. Г. Зазикіна та Н. С. Нечаєвої обгрунтовано відмінності поведінки у конфліктних ситуаціях залежно від статі опонента [4]. Проте досі не достатньо вивченою є проблема гендерних особливостей конфліктних форм поведінки в підлітковому та юнацькому віці.

Формулюваня цілей статті. Здійснити теоретичний аналіз гендерних особливостей конфліктної поведінки у юнацькому віці.

Виклад основного матеріалу. Юнацькій вік - це період життя між підлітковим віком і дорослістю, який характеризується певним внутрішнім дискомфортом, зміст якого пов'язаний із становленням процесів самовизначення, як професійного, так i особистісного (центральне новоутворення юності). Саме тому нерідко віковий етап перебуває у зоні підвищеного ризику [11, c.133].

У цьому віці молоді люди можуть бути дуже вразливими, залежними від чиєїсь думки, схильними до ризику або, навпаки, пасивними, агресивними, мати підвищений рівень тривожності, для них характерні суперечності у міжособистісних відносинах як з однолітками, так і $з$ дорослими. Слід зазначити, що у західній психології переважає традиція об'єднання підліткового віку та юності в єдиний віковий період, так званий «період дорослішання», змістом якого $є$ перехід від дитинства до дорослості, а його межі можуть сягати від 12-14 до 25 років. У вітчизняній науці прийнято розглядати юнацький вік як самостійний період розвитку людини, іiі особистості та індивідуальності (17-21 рік для юнаків і 16-20 років - для юнок) [11, с.133]. Для цього вікового періоду характерна перебудова механізмів соціального контролю: дитячі форми контролю, засновані на дотриманні зовнішніх норм $\mathrm{i}$ слухняності перед дорослими, вже не діють, а дорослі способи, які передбачають свідому дисципліну й самоконтроль, ще не склалися або не зміцніли. Саме це зумовлює перепади настрою: від нестримної веселості до смутку та навпаки, а також ряд інших полярних якостей, що актуалізуються поперемінно [2, с.59].

Отже, особливістю психічного розвитку індивіда у юнацькому віці $є$ активне входження у доросле життя на тлі здійснення особистісного та професійного виборів. Кризи і суперечності юнацького віку в поєднанні з високим інтелектуальним навантаженням та інтенсивним суспільним життям часто призводять до підвищення рівня особистісної тривожності, емоційності, пристрасності й образливості. Неуспішність у основних сферах життєдіяльності юнаків негативним чином впливає на їх самооцінку, підвищує їх конфліктність і призводить до виникнення конфліктів різних типів та на різних рівнях. Щодо розгляду конфлікту в широкому розумінні, то він визначається як зіткнення протилежно спрямованих, взаємовиключних тенденцій окремо взятого епізоду в свідомості, у міжособистісних взаємодіях або міжособистісних стосунках індивідів чи груп людей, пов'язане 3 негативними емоційними переживаннями [3, с.16]. Стосовно суб'єктів науковці виокремлюють чотири типи конфліктів: внутрішньоособистісний (як наслідок амбівалентних прагнень суб'єкта), міжособистісний (виявляється у конфронтації з приводу потреб, мотивів, цілей, цінностей чи становлень), особистісно-груповий (виникає внаслідок невідповідності поведінки особистості груповим нормам та очікуванням), міжгруповий конфлікт (виникає внаслідок зіштовхування стереотипів поведінки, норм, цілей, цінностей різних груп (міжорганізаційні, міждержавні, та ін. конфлікти) [4, с.32].

У існуючій класифікації конфліктів варто звернути увагу на дослідження М. Дойча, який виділив так званий продуктивний конфлікт, що позитивно впливає на динаміку та результативність

Випуск 11, 2018. Збірник наукових праць РДГУ 
соціально-психологічних процесів й служить джерелом самовдосконалення та саморозвитку особистості та деструктивний конфлікт, який спричиняє розлад взаємодії та взаємин взагалі [10, с.28]. Характер поведінки людини у конфлікті залежить як від об'єктивних умов його протікання, зокрема сили сторін, наявності у них групи підтримки, матеріальних та інших ресурсів, якими вони володіють тощо, так і від соціальних характеристик учасників конфлікту, зокрема гендерних відмінностей, тобто відмінностей поведінки, пов'язаних зі статтю учасників конфлікту, зумовлених взаємними непорозуміннями, розходженнями інтересів, цінностей та підходами до розв'язання проблем, що виникають [1].

Гендерні особливості конфліктної поведінки тісно пов'язані з поняттям «статеворольового стереотипу», який включає цінності, мотиви, типи поведінки, в тому числі й конфліктної, які вважають більш прийнятливими для представників однієї статі, ніж для іншої. Вони визначають стиль поведінки чоловіків (хлопчиків) і жінок (дівчаток) у суспільстві і відображають зразки, орієнтуючись на які, люди реагують на представників кожної статі. Формування індивідуальних статеворольових стереотипів відбувається у процесі соціалізації дитини через засвоєння суспільного досвіду. Основну роль у ній відіграють статеворольові уявлення. Вони безпосередньо впливають на формування статевих ролей і статевої ідентичності, виступаючи когнітивною структурною частиною цих елементів психологічної статі. На основі статеворольових уявлень (стереотипів), засвоєння статевих ролей (ідентичностей) формується статева самосвідомість індивіда - усвідомлення себе чоловіком чи жінкою і необхідності виконання відповідних соціальних ролей. Переважно чоловічий стиль поведінки і спілкування характеризується як більш активний, змагальний, предметноінструментальний, а жіночий - як експресивний, залежний, пасивний, емпатійний [7, с.74].

Американський психолог С. Бем запропонувала тест маскулінності-фемінності й на основі його результатів виокремила вісім статеворольових типів і ввела поняття «андрогінний тип» [3, с.241]. У психологічному розумінні з андрогінією пов'язують високі можливості соціальної адаптації. Так, С. Маккобі і К. Джеклін звертали увагу на те, що висока фемінність у жінок часто пов'язана зі заниженою самоповагою і підвищеною тривожністю. Пізніше довели, що високомаскулінні чоловіки і високофемінні жінки мають більше труднощів у тих видах діяльності, які не відповідають традиційним статеворольовим стереотипам, тоді як андрогінні особистості з високими потенціями маскулінності і фемінності легше змінюють тип і стиль діяльності залежно від умов, менше піддаються дистресам [10, с.147].

Звернувшись до проблеми гендерних особливостей у юнацькому віці, зазначимо, що у старшому шкільному віці відбувається активне експериментування з засвоєними раніше моделями поведінки чоловіка і жінки. Усвідомлення себе як представника певної статі відбувається у процесі взаємодії з однолітками як своєї, так і протилежної статі. Юнаки і дівчата остаточно усвідомлюють і починають регулювати прояви своєї статевої ролі. Як відзначають Д.Аузубель, Д.Кірк, для юнацького віку характерні підвищення сприйнятливості до соціальної обстановки і відносин між людьми і посилення суб'єктивної значущості статеворольових стереотипів соціальних ролей [5, с. 322].

У дослідженні І. Кузнецової доведено, що юнаки та дівчата по-різному уявляють собі, якими мають бути сучасні дівчина і юнак. Великі відмінності в оцінках спостерігаються за особистісними якостями, які утворюють i конкретизують поняття «жіночність»: довірливість, дбайливість, лагідність, милосердність, ніжність, поступливість. Для юнаків в цілому характерна тенденція до високої оцінки в дівчатах традиційно жіночих якостей. Сучасні дівчата, не акцентуючи цих якостей у своїй зовнішності, виявляють тенденцію до нівелювання статеворольових і загальнолюдських якостей. Юнаки вище, ніж дівчата, оцінюють ті якості особистості, які традиційно вважаються чоловічими. Зі статеворольових якостей юнаки найвищими балами відзначили такі якості, як воля, сміливість, сила характеру, самовладання. Дівчата надали перевагу великодушності, надійності, відповідальності, тобто саме тим якостям, які проявляються перш за все по відношенню до інших людей, зокрема, по відношенню до дівчини. У цілому, дівчата більшою мірою орієнтовані на загальнолюдські якості [11, с.248].

Є. Ільїн виявив, що чоловіки і жінки по-різному вирішують конфліктні ситуації, що виникають у сімейному і домашньому колах. Жінки виявляють більше терпимості і прагнення до компромісного примирення інтересів. Чоловіки у цій ситуації частіше прибігають до «міцних» висловлювань і лайок, а жінки швидше готові заплакати [5].

За даними Б. Фрідан, відносини між чоловіками характеризуються так званою конфліктністю i змагальністю. Конфліктні відносини між собою хлопчики з'ясовують за допомогою сили, відкидаючи більш слабкого. Конфліктні ситуації між дівчатками вирішуються на емоційному рівні, у суперечках, бойкотуванні. Вони частіше «наговорюють» одна на одну [11, с.249]. 
Зокрема в роботах Ремшмідта X. зазначено, що конфлікти з однолітками в юнацькому віці найчастіше пов'язані з суперництвом і боротьбою за лідерство. Конфлікти на грунті суперництва відбуваються як між хлопцями, так і між дівчатами. Хлопці змагаються за лідерство в групі, за успіхи у фізичній та інтелектуальних сферах, за дружбу і прихильність. У дівчат конфлікти виникають переважно через суперництво за прихильність більш старших за віком хлопців. Визначено ряд специфічних гендерних відмінностей конфліктів. Зокрема, визначено специфічні відмінності конфліктів у чоловічих і жіночих колективах. Так, виявлено, що конфлікти у чоловічих колективах за своєю спрямованістю, емоційними проявами, спектром і накалом емоцій, а також способами конфліктної протидії суттєво відрізняються від конфліктів у жіночих колективах. В чоловічих колективах більше конфліктів, які мають виробничу та ділову основу, в той же час у жіночих колективах більше конфліктів, які мають емоційні основи та викликаються іноді не прогнозованими коливаннями настрою, різноманітними емоційними реакціями і зовні немотивованими вчинками, симпатіями/антипатіями тощо. Визначено, що чоловіки у конфліктах більш схильні орієнтуватися на розв'язання актуальних життєвих завдань, у тому числі, і конфліктних ситуацій, вони більш схильні до ділових реакцій і конструктивного розв'язання суперечок. У той же час жінки більшою мірою орієнтуються на додержання норм, правил, стандартів, ролей [5, с.143].

На думку Кона I.C., юнаки у спілкуванні з представниками протилежної статі орієнтуються в основному на ровесниць, а дівчата в значній їх частині - на більш старших представників чоловічої статі $[6$, с.140]. Вважається, що конфлікти між жінками вирішуються більш складно у зв'язку з наступними гендерними відмінностями жіночої статі у конфліктних ситуаціях: емоційна або прагматична спрямованість; висока емоційність реакцій та переживань; емоційність та накал прояву конфліктності; значне внутрішне суперництво між жінками; ревнощі жінок та їх мікроугрупувань до успіху жінок, що стоїть осторонь, ії успіху у чоловічому соціумі, уваги та визнання з боку чоловіків; зниження нормативності поведінки [6, с.141].

Встановлено, що чоловіки вирішують конфліктні ситуації в основному засобами сили, погроз, маніпуляцій. Доведено, що саме чоловіки можуть бути менш гнучкі і більш ригідні у конфліктах, їх прогнозуванні, упередженні та розв’язанні. В той же час жінки більш витончені маніпулятори, гнучко i точно оперують саме емоційними станами учасучасників конфліктів і досить легко справляються 3 розв'язанням конфліктних ситуацій. [10, с. 144].

Гендерні особливості конфліктів виділяються і в різностатевих, змішаних колективах. Визначено, наприклад, що поведінка чоловіків та жінок у конфліктах значною мірою залежить від статі опонента. Наприклад, у конфліктах з чоловіками чоловіки виявляють високу впевненість, цілеспрямованість, гнучкість. У той же час жінки у конфліктах ведуть себе зовсім інакше, для них стать опонента не є значущим чинником їхньої поведінки, однак $\epsilon$ суттєвим чинником їх особистісних реакцій, симпатій, конструктивності і гнучкості рішень [4, с.36].

Результати емпіричного дослідження Ю. Бабаян та І. Скачко показали, що юнаки, на відміну від дівчат, є більш конфліктними; у міжособистісних стосунках у юнаків переважає домінування, а у дівчат - дружелюбність [1].

У ході дослідження стратегій поведінки студентів у конфліктній ситуації Г.Москалик та М.Булах було встановлено, що для розв'язання конфлікту юнаки частіше обирають суперництво та компроміс, тоді як дівчата - пристосування і співробітництво. Стратегія уникнення, за даними дослідження, у чоловіків і жінок виражена однаково [9, с.98 ]. Жінки при вирішенні конфліктів більше орієнтуються на думку інших, що пояснюється їх значною конформністю. Саме тому при вирішенні конфлікту за участю жінок велика роль відводиться посереднику. Вони, як стверджує Л. Котлова, частіше звертаються за допомогою до інших людей, психологів, лікарів та ін., намагаючись зняти психічну напругу за допомогою бесіди. В той же час жінки більш схильні до загострення конфліктної ситуації, тоді як чоловіки намагаються якомога швидше їі вирішити. Хоча і взаємостосунки між чоловіками загалом є більш конфліктними між взаємостосунками між жінками. Як бачимо, поведінка жінок та чоловіків значно різниться у вирішенні конфлікту: вони по-різному сприймають цілі спілкування, для них різна цінність самого конфлікту і вони відрізняються стратегіями вирішення гострих ситуацій $[8$, с.98].

Залежно від особливостей ставлення до конфліктних ситуацій, що притаманні юнакам чоловічої та жіночої статей, стратегії реагування у конфліктних ситуаціях можуть бути класифіковані на такі, що є більш характерними для застосування дівчатами або юнаками. Так, у зв'язку з тим, що у жінок більше розвинена емоційна сфера, для дівчат поведінка у конфлікті частіше пов'язана 3 емоційними проявами (плач, сльози, крик, злість, образа), а також із міжособистісними стосунками (сварка, суперечка, непорозуміння, нерозуміння, недовіра, зіткнення, розбіжність). Чоловіками ж поняття конфлікту сприймається як протистояння і пов'язане з певними поведінковими реакціями

Випуск 11, 2018. Збірник наукових праць РДГУ 
(суперечка, протиріччя, боротьба, сутичка, війна, бійка), а також із міжособистісними стосунками (зрада, відносини, сварка) [9, с.99].

Висновки та перспективи подальших розвідок у даному напрямку. Здійснивши огляд дослідження гендерних аспектів проблеми конфліктної поведінки юнаків, можна виокремити, що характер поведінки людини у конфлікті залежить як від об'єктивних умов його протікання, зокрема сили сторін, наявності у них групи підтримки, матеріальних та інших ресурсів, якими вони володіють тощо, так і від соціальних характеристик учасників конфлікту, зокрема гендерних відмінностей. Типові гендерні властивості умовно об'єднуються у групи ділових та комунікативних якостей, особистісних характеристик. Воля, інтелект, самовпевненість традиційно вважаються чоловічими характеристиками, а щодо жінок, то можна виділити комунікативні, моральні та соціальноперцептивні якості. Гендерна поведінка юнаків у конфлікті пов'язана зі статево-рольовими стереотипами, які зумовлюють зміст та ставлення до життєвого вибору, сприймання конфліктних ситуацій, вибір тактики вирішення протиріч.

Перспективи подальшого дослідження вбачаємо у пошуку ефективних шляхів вирішення конфліктних ситуацій, враховуючи гендерні особливості їх учасників.

\section{Список використаних джерел}

1. Бабаян, Ю.О. Гендерні особливості конфліктної поведінки в юнацькому віці. [Електронний ресурс] / Ю. О. Бабаян, І. В. Скачко // Актуальні проблеми психології. - 2015. - № 38. Режим доступу: http://journals.uran.ua/index.php/2072-г 4772 /article/view/44651.

2. Бантишева О. О. Гендерно-вікові особливості схильності осіб юнацького віку до активної поведінки / О. О. Батишева // Молодий вчений». - 2016 - № 1 (28). - С. 58-63.

3. Гришина Н. В. Психология конфликта / Н.В.Гришина. - СПб.: Питер, 2002. - 464 с.

4. Жевакіна Н.В. Особливості виникнення і перебігу конфліктів у соціальній роботі / Н.А. Жевакіна // Вісник ЛНУ імені Тараса Шевченка. - 2014. - № 4. - С. 31-37

5. Ильин Е. П. Пол и гендер / Е. П. Ильин. - СПб.: Питер, 2010. - 688c.

6. Кірющенко, В. Л. До проблеми гендерної рівності в Україні [Електронний ресурс] / В. Л. Кірющенко, С. О. Гарькавець // Соціально-психологічний та філософський підхід до проблем сучасного матеріали наук. конф. (8.02-01.03.2016). - Сєвєродонецьк : вид-во СНУ ім. В. Даля, 2016. - С. 142-144. Р. дос: http://dspace.snu.edu.ua:8080/jspui/handle/123456789/635 .

7. Кондратюк А. Ю. Гендерні відмінності самореалізації особистості в юнацькому віці / А. Ю. Кондратюк, С. А. Литвиненко // Психологія: реальність і перспективи. Збірник наукових праць РДГУ. - 2014. - № 3. - С. 73-75.

8. Котлова Л.О. Гендерні особливості конфліктних форм поведінки в підлітковому та юнацькому віці / Л.О.Котлова // Педагогічна освіта: Теорія і практика. Психологія. Педагогіка : зб.наук.пр. / Київ. Київ.ун-т ім.. Б.Грінченка ; редкол.: Огнев’юк В.О., Хоружа Л.Л., Безпалько О.В. [та ін..]. - К.: Київ.ун-т ім. Б.Грінченка, 2013. - № 19. - С.95 - 99

9. Москалик Г. Ф. Гендерні конфлікти студентів / Соціальна філософія та філософія історії // Г. Ф. Москалик, М.О.Булах. - 2017- №11 - С. 93-100.

10. Русинка I. I. Конфліктологія: Психологія технології запобігання і управління конфліктами: Навч. посіб. / І. І. Русинка. - К.: Професіонал, 2007. - 332 с.

11. Скрипченко О.В.Вікова та педагогічна психологія /О.В. Скрипченко. - К. : Просвіта, 2001. - C. 248.

\section{References}

1. Babayan, Yu. O. Genderni osobly`vosti konfliktnoyi povedinky` v yunacz komu vici. [Elektronny`j resurs] / Yu. O. Babayan, I. V. Skachko // Aktual`ni problemy` psy`xologiyi. - 2015. - \# 38. Rezhy`m dostupu: http://journals.uran.ua/index.php/2072-g`4772/article/view/44651

2. Banty`sheva O. O. Genderno-vikovi osobly`vosti sxy`l’nosti osib yunacz`kogo viku do akty`vnoyi povedinky` / O. O. Baty`sheva // Molody`j vcheny`j». - 2016 - \# 1 (28). - S. 58-63.

3. Grishina N. V. Psihologiya konflikta / N.V.Grishina. - SPb.: Piter, 2002. -464 s.

4. Zhevakina N.V. Osobly`vosti vy`ny`knennya i perebigu konfliktiv u social`nij roboti / N.A. Zhevakina // Visny`k LNU imeni Tarasa Shevchenka. - 2014. - \# 4. - S. 31-37.

5. Ilin E. P. Pol i gender / E. P. Ilin. - SPb.: Piter, 2010. - 688 s.

6. Kiryushhenko, V. L. Do problemy` gendernoyi rivnosti v Ukrayini [Elektronny`j resurs] / V. L. Kiryushhenko, S. O. Gar`kavecz` // Social`no-psy`xologichny`j ta filosofs`ky`j pidxid do problem suchasnogo materialy` nauk. konf. (8.02-01.03.2016). - Syevyerodonecz`k : vy`d-vo SNU im. V. Dalya, 2016. - S. 142-144. R. dos: http://dspace.snu.edu.ua:8080/jspui/handle/123456789/635. 
7. Kondratyuk A. Yu. Genderni vidminnosti samorealizaciyi osoby`stosti v yunacz komu vici / A. Yu. Kondratyuk, S. A. Ly`tvy`nenko // Psy`xologiya: real`nist` i perspekty`vy`. Zbirny`k naukovy`x pracz` RDGU. - 2014. - \# 3. - S. 73-75.

8. Kotlova L.O. Genderni osobly`vosti konfliktny`x form povedinky` v pidlitkovomu ta yunacz`komu vici / L.O.Kotlova // Pedagogichna osvita: Teoriya i prakty`ka. Psy`xologiya. Pedagogika : zb.nauk.pr. / Ky`yiv. Ky`yiv.un-t im.. B.Grinchenka ; redkol.: Ognev'yuk V.O., Xoruzha L.L., Bezpal`ko O.V. [ta in..]. - K.: Ky`yiv.un-t im.. B.Grinchenka, 2013. - \# 19. - S.95 - 99.

9. Moskaly`k G. F. Genderni konflikty` studentiv / Social`na filosofiya ta filosofiya istoriyi // G. F. Moskaly`k, M.O.Bulax. - 2017- \#11 - S. 93-100.

10. Rusy`nka I. I. Konfliktologiya: Psy`xologiya texnologiyi zapobigannya i upravlinnya konfliktamy`: Navch. posib. / I. I. Rusy`nka. - K.: Profesional, 2007. - 332 s.

11. Skry`pchenko O.V.Vikova ta pedagogichna psy`xologiya /O.V. Skry`pchenko. - K. : Prosvita, 2001. - S. 248.

N. O. Hypavtseva, N.V.Rechun. THE PROBLEM OF THE RESEACH OF THE CONFLICT BEHAVIOUR IN YOUTHFULL AGE (THE GENDER ASPECT).

In the article the content of the notions of "conflict" and "conflict relations" have been disclosed. Public life can not exist without the clash of ideas, attitudes, goals, both in individuals and in small / large groups. Regularly there are the differences of opinions and all sorts of contradictions and they often lead to into conflicts. When people think of conflict they often associate it with aggression, threats and disputes. The article presents the basic ideas of scientists on the phenomenon of interpersonal conflict and presents a generalized picture of the basic strategies of behavior in conflict. It has been determined that the behavior of a person in a conflict depends on the objective conditions of the conflict, and social characteristics of the participants of the conflict, in particular, gender differences. Gender differences i.e. differences of behavior connected with sex, lead to the conflict caused by mutual misunderstanding, the differences of interests, of values and of approaches to solving problems. It has been revealed that the behavior of men and women is very different in resolving the conflict, i.e they differently perceive the goals of communication, they differently value the conflict, and they have different strategies for tackling the acute situations. The adolescents have extremely a cute conflicts and this is a characteristic feature of this age period. Conflicts for adolescents are a means of self-assertion of the individual, of the formation of its active role in the interaction with the environment. Their conflicts with peers are often connected with the competition and the struggle for leadership. Conflicts occur on the basis of competition both among boys and among girls. Boys compete for the leadership in the group, for the success in physical and intellectual spheres, for friendship and affection. Girls clash mainly because of the competition for the attention of older boys.

Key words: conflict, conflict relations, resolving the conflict, youthfull age, interpersonal conflict, gender differences. 